\title{
Technology Transfer and International Integration of Developing Countries: An Empirical Investigation of Tunisian's Case
}

\author{
Nadia Selmi \\ FSEGT, El Manar University, Tunisia
}

\begin{abstract}
The objective of this paper is to elucidate empirically the relationship between technology transfer, productivity growth and integration of the Tunisian economy emphasizing the issued technology on the one hand and the absorptive capacity of Tunisia, on the other. Indeed, technology transfer is far from being a simple and automatic process. To do this we have mobilized an original database providing data from technology- sending countries (OECD) to developing ones (MENA) for eleven years. The results achieved show significant causal relationship between technology acquired, the increase of the TPF level on the one hand and the integration degree of Tunisia expressed by its opening rate on the EU market on the other hand. Nevertheless, the relationship between technology transferred and integration is far from being direct and systematic, it depends largely on absorptive capacity of the host country. We have also highlighted the opportunity offered to Tunisia to achieve its objectives of integration in the European and world market while indicating that Tunisia is not taking enough advantages from its proximity to Europe to increase exports and attract FDI which are far from being interesting for the moment.
\end{abstract}

Keywords: Technology transfer, absorptive capacity, total factor productivity, integration.

\section{Introduction}

An examination of international trade theories and new growth theories reveal how the economic development, the successful integration and growth are more closely related to the mastery of technology and the ability to adaptation from one country to the technological innovations. Therefore, the objective of versatility and upscale exports and successful integration into the global economy forced an emerging economy such as the Tunisian one to the creation and accumulation of new technological capabilities. However, being still unable to produce its own technology, Tunisia is forced to look outward to develop this technology, since the use of such a transfer affects the ability of the productive sector to modernize and compete in markets increasingly opened to foreign competition.
We will attempt to elucidate the interactions and interferences that may exist between the transfer of technology and the dynamics of integration and the potential impact of these interactions on the process of integration of Tunisia. Thus, through this exercise we will try to understand the relationships and intersections that may exist between the two variables of this research, namely, technology transfer and integration of Tunisia.

Thus, the aim of this paper is to investigate empirically the relationship between technology transfer, productivity growth and integration of the Tunisian economy and this, in order to verify the theoretical expectations. We are, first, presenting a summary of the main theoretical essays dealing with this issue and then with the empirical model in which we will establish

Copyright (C) 2012 Nadia Selmi. This is an open access article distributed under the Creative Commons Attribution License unported 3.0, which permits unrestricted use, distribution, and reproduction in any medium, provided that original work is properly cited. Contact author: Nadia Selmi E-mail: selmi.nadia@yahoo.com 
a system of two equations in the time series in order to explain the impact of different aggregates built on productivity and on the integration of Tunisia. We will focus on technology issued on the one hand and on the absorptive capacity of Tunisia on the other. Indeed, the successful integration of developing countries depends not only on their own efforts in R \& D but also on the efforts of $\mathrm{R} \& \mathrm{D}$ of trading partners and thus the stock of R \& D is transferred to the developing countries. We will also check the conditions for the success of technology transfer which, according to theoretical expectations, depends on the absorptive capacity of the country receiving the technology. To do this we have mobilized from the data bases Chelem, the World Bank and the IMF and we have referred to the period extending from 1987 to 2008 .

Since the diffusion of technology is not directly observable, we are going to define a variable- DTM- which will allow us to measure the flow of technology that is transferred. This technology is apprehended through two transfer channels: international trade and FDI.

TFP, in turn, is evaluated based on an estimate of the production function to identify the capital and labor elasticity introduced to construct the said variable.

To measure the degree of integration, we are going to use the indicator of trade integration defined by the OECD, the international trade ratio / GDP [ $\mathrm{X}+\mathrm{M})$ / GDP]. Indeed, the international trade in goods traditionally represents the major route of economic integration. It is the most commonly used indicator to measure the extent and degree of international transactions relative to domestic transactions.

The works of reflection on the technology and integration, which were developed by leading experts, (eg Nelson and Winter 1982, Dosi, 1984, Krugman, 1986, Romer, 1986.1990, Lucas 1988, Grossman and Helpman , 1990, Aghion-Howitt, 1992, Baldwin and Venables, 1995; Maurel, 1999; Fontagné, 2000) insist on increasing returns and imperfect competition and the view which states that technological change is a key factor in the redefinition of the international specialization of exports.

By applying to the case of Tunisia, this restructuring of the productive system through improved productivity, which is responsible for improving the competitiveness of the economy and thus determining the success of its integration.

We will follow the estimate to the interpretation of the results found when we try to draw conclusions about the experience of Tunisia in terms of integration.

\section{II -The Empirical Verification of the Relationship between Technology Transfer and Integration}

\section{II-1 Technology Transfer through International Trade}

Briefly, according to the traditional theory of international trade, the exchange is regarded as a process to streamline and organize the productive structure of an economy. This reallocation of resources, leads to a country's specialization in industries for which it is relatively more efficient. This redeployment of resources from less efficient to more efficient should help to increase TFP. (SYRQUIN [1986], FEDEN [1986], DOWRICK [1989], DOWRICK \& GEMMEL [1991], POIRSON [2000]). Under these conditions, the developing countries who specialize in intensive- labor industries attend to an increase in productivity. This productivity growth is particularly noteworthy that the country is a low level of development and able to attract human and physical capital (POIRSON [2000]). Regarding the new trade theory assuming an analytical context of endogenous growth, it incorporates a dual mechanism by which the exchange contributes to productivity growth. (ROMER [1990], RIVERA-BATIZ \& ROMER [1991], GROSSMAN \&HELPMAN [1991b], AGHION \& HOWITT [1992]. On the one hand, it directly stimulates the growth rate of a country either by increasing the amount of inputs available on the market, or by improving the quality of intermediate 
goods. On the other hand, international trade represents a process through which technological knowledge is conveyed internationally. As explained by KELLER [1997] "Importing a foreign intermediate good [...] allows a country to capture the $R \& D$ or 'technology-content' of the good. For a given primary resources, productivity is increasing in the range of different intermediate goods which are employed, due to the assumption that they are imperfect substitutes for each other. The model predicts that total factor productivity is positively affected by the country's own $R \& D$, as well as by $R \& D$ investments made by trade partners. " Therefore, international trade is seen as a vehicle for the dissemination of knowledge. The latter is at the level of the imported product that incorporates information technology. The developing countries, unable to produce knowledge, must rely on foreign imports and use them as a source of accumulation of technology. Besides, these imports of capital goods and in the same logic, FDI represent- for many developing countries which do not have a technological advantage- a substitute or a complement to the development of national research activities.

As part of this theoretical context, many recent studies have recognized the import assistance in the transfer of foreign technologies and the contribution of these technologies to increase productivity (Coe et Helpman, 1995; Coe, Helpman et Hoffmaister, 1997; Enenson, 1995; Keller, 1997, 1998a, 1998b). Coe and Helpman, the pioneer of these studies found a positive correlation between the level of TFP and technological content of imports on the one hand and their structure on the other hand. They have thus verified empirically about Romer (1990), Aghion and Howitt (1992) studies showing that spending on research and development in the issuing country contributes to increase TFP receiving country through imports. However, the interpretation of these findings is not clear so far. By using the same data, Keller (1998a) showed that positive causality between technological content of imports and the level of TFP is verified except that, unlike Coe and
Helpman, the composition of imports has nothing to do with it. He believes that the nature of imports just happens by chance. In a subsequent study in which he incorporated the effect of the structure of imports, Keller (2000) finally admitted that not only does the nature of imports affect TFP receiving country but also the weight of each category in total imports. All things being equal, these imports should absolutely emerge from countries with a high level of qualification. Moreover, this knowledge transferred should not be passively used. For this, we must have an absorptive capacity, prerequisite for the success of the transfer process. Empirical verification of these theoretical expectations, was provided by the work of Jaffe (1986), Eaton, Gutierrez et Korton (1998) , Griffith \& al (2000). Thus, Jaffe (1998) found that the greater the stock of research and development in the host country, the greater the benefits of the process of technology transfer are distinguished. Furthermore, using data on levels of industrial OECD countries, Griffith and al (2000) found that research and development in the host country increase the rate at which technology is transferred.

In the same line of ideas, other studies (Acemoglu et Zillibotti (2001), Hall and Jones (1999), Harrigan (1999) and Prescott (1998)) examined the convergence of productivities of different countries and found differences in productivity levels between countries. This divergence between productivity levels is closely related to differences in absorptive capacity. For example, Benhabib and Spiegel (1994) emphasize the vital role of human capital in promoting productivity while Abramovitz (1986) focuses instead on social capacity. Once the transfer process is completed, the economy, for a successful integration into the international market, is expected to build new technological capabilities and opt for an adequate specialization strategy positioning on dynamic products and / or markets expanding. Empirical works on the impact of specialization on economic performance are not numerous. Busson and Villa (1997) have shown that the opening of the economy to international 
trade boosts growth significantly in two cases: on the one hand when the country can position itself in areas where global demand is strong (Note to this effect, that now this demand shifts more on products with high technological content) and the development of intra-industry trade that allows a wide variety of intermediate goods and high contenting-capital goods, on the other hand. This adequate specialization which precisely ensures a competitive position of the industry on the world market and therefore the success of integration. In addition, CEPII studies have supported the thesis that specialization of a country in a developing- international demand areas represents a significant growth potential (Bensidoun \& ÜnalKesenci 1998 ; Bensidoun, Gaulier \& ÜnalKesenci 2001). Moreover, according to other studies, some specialties are more conducive to growth under product features that have particularly significant potential for learning by doing (Young 1991) or a high level of quality and technological content (Grossman and Helpman, 1991).

However, other highlighted empirical results suggested that technological externalities benefit all countries, particularly developing countries. However, this supposed uniformity of technological diffusion is unlikely for two reasons. First, imports, expected to contribute to the diffusion of technology, are influenced by geographical factors and particularly by the physical distance between importers and exporters, which was demonstrated by studies based on gravity models (Frankel et al., 1996, Frankel and Romer, 1999). Second, the technological diffusion depends itself on physical proximity between transmitter and receiver of knowledge and seems to be confined to reduced geographical areas (Eaton and Kortum, 1996; Keller, 2001). Therefore, it seems appropriate to highlight the issue of the geographical location of countries to study the diffusion of technology generated by international trade and its impact on growth. Thus, the problem of relationship that may exist between technology diffusion and geographical location was taken into account by a large part of the work built in the field of spatial economics. The main idea advanced by Marshall states that among the determinants of geographic concentration of productive activity (called localization effect), technological externalities play a key role. The geographic concentration of firms facilitates the knowledge spreading, due to the proximity of firms to each other.

This vision later causes a set of empirical studies conducted in the framework of the model MAR (Marshall-Arrow-Romer) confirming the existence of a technological diffusion localized in large U.S. conglomerations, diffusion which contributes significantly to the development of the innovative capacity of firms located in these cities (Audretsch and Feldman, 1996; Henderson, 1997; Anselinet al., 1997). Geographical proximity is known to play a role in the transmission of knowledge, while tacit information dissemination remains unchanged to this factor. In addition, the works of Jaffe and Jaffe \& al demonstrate more explicitly the relationship between technology diffusion and geographical proximity. These studies suggest visualizing the transfer of technological knowledge through the examination of patent citations, only tangible evidence of the knowledge transfer. Empirical results led by these studies show that technological diffusion is often limited to intra-industry level. For its part, Branstetter shows that diffusion is more intense within the United States and Japan than it is between the two countries. Eaton and Kortum demonstrate that patenting activity is negatively correlated with physical distance. Based on the estimates made, the authors conclude that technological diffusion reaches its minimum when the distance is $10,000 \mathrm{~km}$.

Given this work, global reach and consistency of technological diffusion are less clear, although the hypothesis of learning through technological externalities remains quite plausible (Grossman and Helpman, 1990). Therefore, it is useful to reconsider this hypothesis taking into account the issue of location. 
This is, among other reasons, why we have considered- in the context of our modeldata related to the European Union.

\section{II.2. Technology Transfer through FDI}

Considering FDI, several empirical studies have attempted to describe the relationship between FDI, the technological diffusion and the economic growth in host countries. These studies indicate that in the first five years of commercialization, new technologies are spreading abroad primarily through subsidiaries of multinationals and not through exports. In most cases, it appears that the technology transferred to affiliates are- on averagemore recent than those transferred to a third by a set of licenses or joint ventures (WTO 1996). Empirical studies led by Blomstrom, Kokko and others converge with the idea that FDI is an important, even the most important vector of the technology transfer to developing countries. These studies also agree on the fact that the importance of technology transfer allowed by FDI, varies according to the characteristics of the industry and the host country: greater competition, more training of fixed capital, a higher level of education and less restrictive conditions imposed on subsidiaries are all factors that promote technology transfer. In addition, foreign companies can, through direct competition they do implement the local market and the ripple effect on domestic firms, increase the level of productivity in the sector in which they operate. Indeed, Caves (1974) examined the consequences, in terms of value added per worker, of the foreign presence in the Australian manufacturing sector and identified that the gap between foreign and domestic value added tends to disappear as presence in the sector increases. This is likely to reap the convergence of productivity levels to those of developed countries. Blomström (1991), on the other hand, speculates that the productivity growth of Mexican firms is especially important in areas that reflect a greater participation of foreign investors. Nevertheless, the overall performance of the economy cannot be stimulated only by the presence of a better educated workforce and the availability of technological and organizational knowledge transferable to the rest of the economy. This point is fundamental for the development of the less advanced economies. Many empirical studies corroborate this argument. Borensztein, De Gregorio and Lee [1995], established through econometric tests conducted on 69 developing countries, that the manifestation of this effect is closely related to human capital held by the host economy. The effect of FDI on economic performance and growth is as tangible as the education system is effective. In the same line of thought, KATZ [1987] verifies that the Latin American countries have received knowledge management through the FMN which have previously formed individuals. YOSHIMARA [1988] came to the same conclusions for China and GERCHENBERG [1987] for Kenya. However, other authors support the argument that FDI promotes an organizational truncated structure that leads to a tertiary of the economy. Eventually, an emigration of productive frameworks leading to a reduction in the country's economic efficiency is expected. As noted DALY \& GLOBERMAN [1976], the appearance of this structure results in a fragmentation of industrial activity rather than rationalization.

\section{III-Empirical Study of the Relationship between Technology Transfer and Integration}

The data used for this study come primarily from the database of the World Bank entitled "World Development Indicators" (2010) (from which we collected data on GDP at current prices, gross fixed capital formation, labor and FDI from EU countries) and the database Slam (2009) (exports by product and country, imports by product and country and the opening rate). Observations are annual and the sample consists of data on the aggregates, of the EU countries and Tunisia. In addition, drawing on the work of Benhabib and Spiegel (1994) and Crespo and al. (2002), we constructed a database for Tunisia and the EU countries. Our contribution is to improve the effectiveness 
of variables: absorption (denoted CA) and technological diffusion (denoted DTM).

\section{III-1 Construction of Variables and Estimation Model}

\section{III-1-1 Technology Diffusion:}

To construct this variable we have chosen, for reasons of data availability, only two main channels of technology transfer, international trade and FDI flows. We have assumed, in accordance with theoretical expectations that foreign technology is conveyed by the import of capital goods (meq) (and not the total imports (M)) from the EU on the one hand, and FDI flows from the EU on the other hand. The choice of referencing in relation to the $\mathrm{EU}$ is motivated on one side by the geographical proximity and on the other by the fact that trade with the EU represents $80 \%$ of the total trade in Tunisia as well as the volume of FDI which is of the order of $71 \%$. Thus, it is clear that successful integration of Tunisia in the global market come inevitably through a perfect integration in the European space. Our findings will, therefore, consider the integration opportunities of Tunisia in the EU market. This integration into the European space, if successful, represents a first step towards integration into the international market. Hence the following relation:

$$
D T M_{t}=\frac{m_{e q_{t}}}{M_{t}} \log \left(M_{t} \frac{R D_{t}}{G D P_{t}}\right)+\frac{F D I_{U E}}{F D I_{\text {total }}} \log \left(F D I_{\text {total }} \frac{R D_{t}}{G D P_{t}}\right)
$$

$M_{t}$ : total imports of Tunisia from the EU.

$\frac{R D_{t}}{G D P_{t}}$ The share of R \& D in the EU GDP

$\frac{m_{e q_{t}}}{M_{t}}$ The share of imports of capital goods in total imports of Tunisia from the EU
$F D I_{U E}$ Foreign direct investment from the EU

$F D I_{\text {total }}$ Total foreign direct investment to Tunisia

The resulting series of DTM has the following characteristics:

\section{DTM}

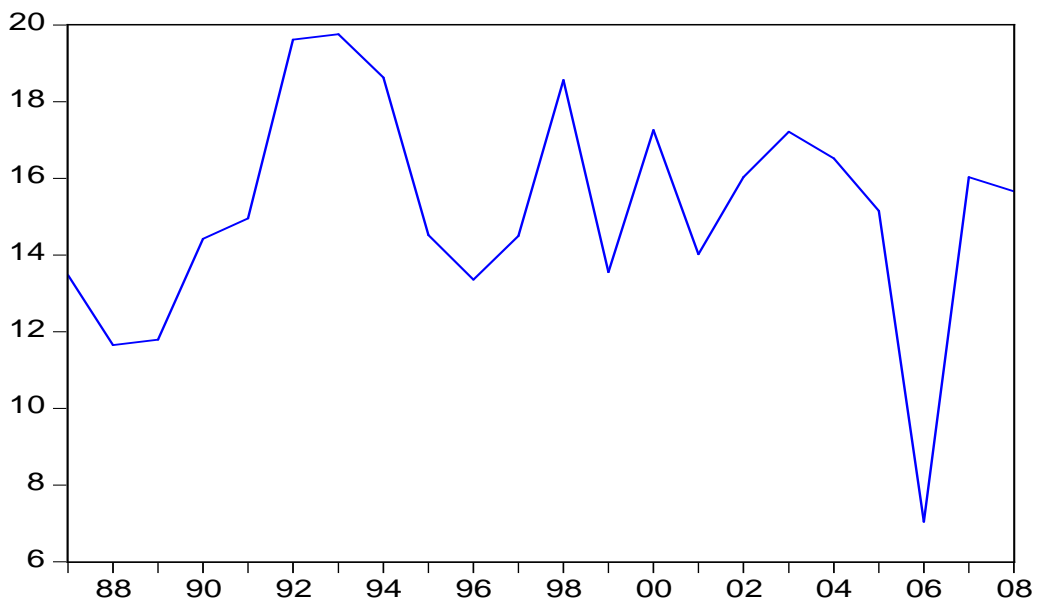

Fig 1: DTM

This chart shows that the technological diffusion behaves unstably. Indeed, the evolution of the variable is characterized by alternating upward and downward and continued his swing until 2006 where the level of technological diffusion has reached its minimum to restart and show a significant improvement in 2007 even a consolidation in 2008. This reflects the non stationarity of the variable even around a trend. We particularly emphasize the alarming decline of technology transfer in 
2006, this is a consequence of the decline of FDI contribution in the import of technology. In fact, this year was marked by a decline in FDI flows from the EU, consequence of the degradation of French investments. Note to this effect, that France, with the largest number of foreigninvested enterprises (40\% of total) and employing more than a third of FDI employees in Tunisia remains in the first place, ahead of Italy and UK.
A match, France remains by far the largest trading partner of Tunisia. It is the leading supplier with $25 \%$ of imports and its first customer, with $33 \%$ of exports. Thus, the increase in the value of technological diffusion is due, under major infrastructure projects undertaken by Tunisia, to the increase in imports of capital goods from France. Indeed, contracts, whose implementation started in 2006, were signed between the two countries.

Table $n^{\circ} \mathbf{1}$

\begin{tabular}{|l|l|l|l|l|}
\hline DISPERSION & average & median & $\begin{array}{l}\text { Standard } \\
\text { Deviation }\end{array}$ & $\begin{array}{l}\text { Coefficient of } \\
\text { variation }\end{array}$ \\
\hline VALUES & 15.16894 & 15.05653 & 2.912904 & 5.207497 \\
\hline
\end{tabular}

Interpretations from the graph above are confirmed by Table 1 . The variable displays a value of 15 , which varies significantly with time, with a relatively high standard deviation and coefficient of variation indicating a temporal variability between about 5.2. This average value means, a priori, that only $15 \%$ of imported technology is diffused by Tunisia in the industrial system. Although non-stationary, a value of 15 of the median $\approx$ the average, indicates that the variable DTM behaves stably around its mean value. Being much higher than zero, the standard deviation and coefficient of variation show that this value of 15 is far from a reference value.

\section{III-1-2 The Degree of Integration}

The index measuring the degree of integration established by the OECD is the openness degree defined as (X+M / GDP). This ratio is also known as the degree of trade openness.

\section{III-1-3 The Absorptive Capacity}

Let us note at the beginning the sensitivity and non-outlined characteristic of the absorptive capacity and the risk of aberrant estimation that follows. This variable is constructed by introducing human capital (KH) and the stock of $\mathrm{R} \& \mathrm{D}$. These two components are considered most determinant in the definition of absorptive capacity. It is also to note that the mentioned variable is also a function of several other non-economic factors such as culture, customs and health which contribute in different ways to the adoption and absorption of foreign technology.

- Human Capital (KH)

The empirical works established for the evaluation of human capital revealed that enrollment in secondary or framing ratios do not divulge the true value and the nature of education and consequently the stock of human capital. . ( Barro 1991; Romer et Weil 1992; Barro, RJ et LEE J-V 2000). Most estimate applied to developing countries indicate that enrollment is not significant. Note, however, that these countries do not stop increasing spending on education, however, this increase has not materialized by improving the skills of outgoing which has even deteriorated.

Thus, to improve the efficiency of the human capital variable, we use the methodology of Altinok Nadir (2006) that we follow in our approach.

The approach makes a rally series on common scales in order to have indices of comparable educational quality (IQE). We rely on the data series related to education in Tunisia reflecting the level and educational policy. (Education expenditure per GDP, education expenditures per GDP, enrollment, Score coaching, ...). 
We define a scale of 0-100 for all series. Then we proceed to an anchorage of scores determined with each other to obtain a composite indicator that measures the quality of education in Tunisia between 0 and 100. It is obvious that the higher the value of the indicator is close to 100 , the better the quality of education is. We establish thus scores that we have used:

S1: Education expenditure per GDP

\section{S2: Educational expenditure per GDP}

\section{S3: The enrollment rate}

S4: The score framing $=100-$ (enrollment ratios $=$ pupils per teacher)

All scores range between 0 and 100, where the variable $\mathrm{KH}$ :

$$
K H=\frac{\sum_{i=1}^{4} S_{i}}{4}
$$

\section{$\mathrm{KH}$}

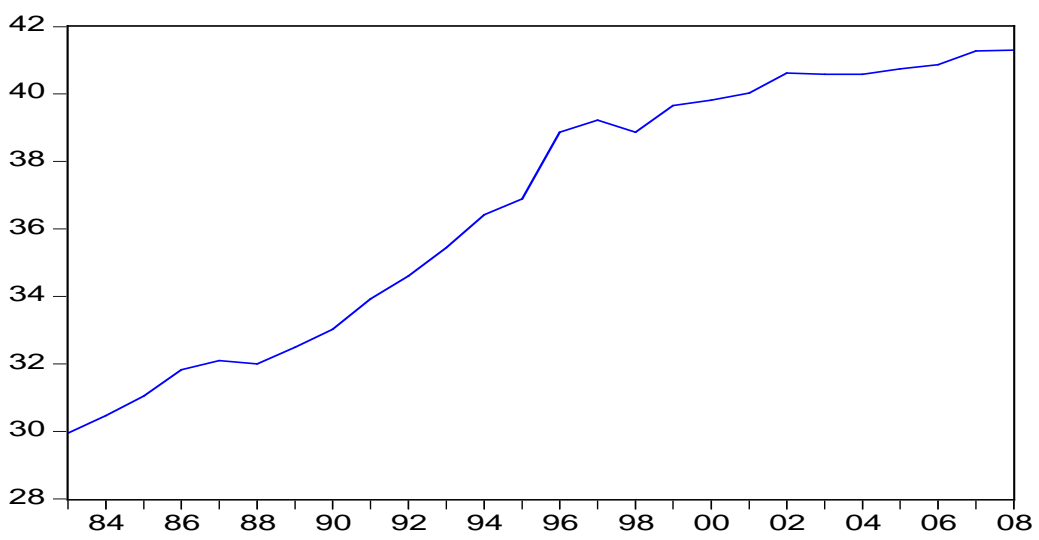

Fig 2: KH

This graph shows that human capital follows a trend, rather higher, except for a few small decays. Such behavior is the result of reforms for the sectors of education, higher education and vocational training which were accelerated to improve their performance and enhance their assistance in building the knowledge economy and the achievement of development goals.

Indeed, several laws and measures have been initiated including the orientation law related to education and schooling, the plan to upgrade the training and consolidation of the decentralization of higher education. This strategy has contributed to the consolidation of the various educational indicators and the increase of their performance.

Certainly, enrollment at different levels have improved especially in higher education where for the 20-24 age group, it reached $37.5 \%$ during the 2007-2008 academic year against only $14 \%$ in 1996 1997. It is the same for the slice 6-14 years which has evolved from $86.2 \%$ in 1994 to $96 \%$ in 2006.

Student enrollment (public and private) grew at a steady pace to land about 366 thousand during the 2006-2007 academic year against 121,800 during the 1996-1997 academic year. Similarly, we derive the same rate capacity of the vocational training device where the enrolled increased from 14,600 in 1996 to about 78,000 in 2006. We also note the work done with the aim of diversifying education courses, consolidating adequate specialties, expanding the network of universities from all regions and providing education and training tools to respond positively to technological changes.

The interaction between educational systems, higher education and vocational 
training, on the one hand and the productive system and the requirements of integration and growth, on the other, continues to represent one of the key areas of future interventions.

Therefore, by reference to Crespo \& al's work. (2002) we define the variable absorptive capacity using the method of principal components analysis (PCA) where we introduce three variables, namely spending on research and development by GDP, human capital and health spending relative to GDP. The latter was introduced to the requirements of the PCA estimates as the relevance of coefficients is obtained only from three variables. It should be pointed out that the health of individuals plays a significant role, though less important in determining the absorptive capacity of a country. Conscious, among other things, of the size of the impact in terms of absorptive capacity of a healthy population, the government has instituted major reforms which have focused on the modernization of hospitals and the introduction of greater efficiency in their management methods and the raise of the efficiency of regional hospitals.

These reforms have affected similarly, the consolidation of preventive medicine, basic health, emergency medicine, the health information system and the improvement of the quality of care delivery. Particular attention has also been given to health financing and transparency of the relationship between health care providers and social security funds through, especially, the progressive institution of billing regime. Thus, to measure it, we have used the variable of health expenditures that we have incorporated into the estimation equation. We obtain:

$$
C A_{t}=0,401 * R D_{t}+0,565 * K H_{t}
$$

$R D_{t}$ : The share of $\mathrm{R} \& \mathrm{D}$ in GDP of the receiving country, Tunisia.

\section{CA}

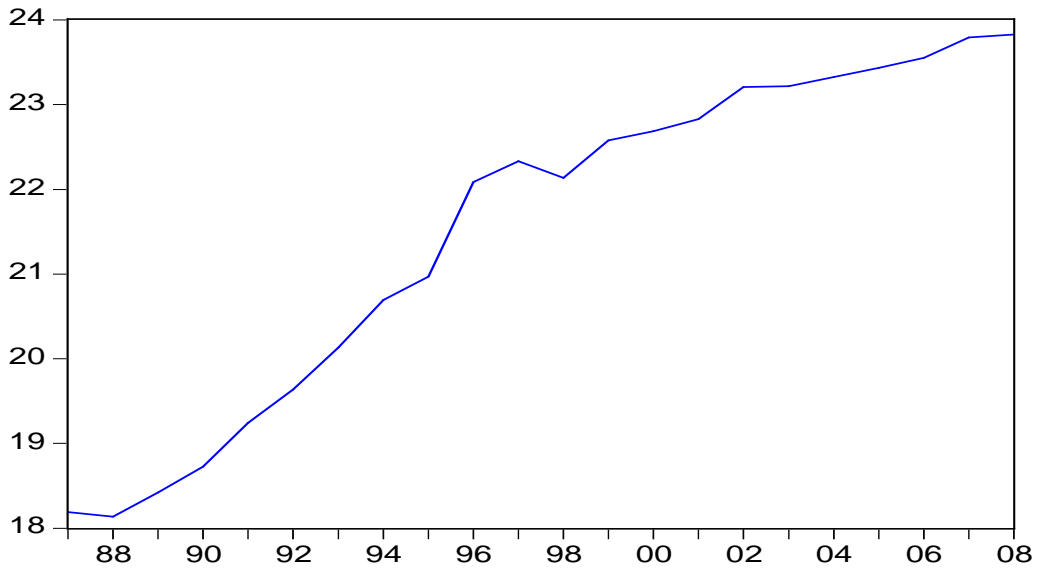

Fig 3: CA

We note that the two main components of absorptive capacity have close weights $(0.4$ for research and development and 0.5 for human capital), which is coherent with the government policy which gives more importance and attention to investment in human capital and research and development expenditures. Certainly, investment in the education sector, education and training is a key factor in the development of human capital viewed as the best way to acquire the skills and competencies necessary to achieve the objectives and emerging technological challenges. 
Table $n^{\circ} 2: R \& D$ Indicators

\begin{tabular}{|l|l|l|}
\hline & 1998 & 2008 \\
\hline Number of researchers in full time equivalents & 6563 & 17533 \\
\hline Number of research laboratories & 16 & 146 \\
\hline Number of research unit & 26 & 38 \\
\hline R \& D expenditures(\% of GDP) & 0,43 & 1,19 \\
\hline
\end{tabular}

\section{III-1-4 The Total Factor Productivity}

Economic performance of a nation depends, on the one hand, on the effort of capital accumulation and on the increase in labor and on other innovative capacities on the other hand, or otherwise on the acquisition of this innovation and a set of qualitative variables reflecting a better use of physical production factors, a business framework conducive to the development of economic activity, mastery of supply chains and marketing, etc.. whose contribution to the competitiveness of exports can be evaluated through the total factor productivity of which we estimate the expression and the behavior.

Productivity is defined as the ratio between GDP and the number of the active population. While total factor productivity is defined by the following formula:

$$
T P F_{t}=\frac{G D P_{t}}{K_{t}^{\alpha} L_{t}^{1-\alpha}}
$$

$K_{t}$ Is the stock of physical capital and $L_{t}$, the labor

Thus, we have $\log \left(T P F_{t}\right)=\log \left(G D P_{t}\right)-$ $\alpha * \log \left(K_{t}\right)-(1-\alpha) \log \left(L_{t}\right)$
We must note that the capital and labor elasticities are not directly observable and their determination is performed through an estimation of the production function. Thus, to estimate Tunisia's production function, we use an augmented Solow type neoclassical production function (Mankiew. Romer and Weil 1992). This function takes the following form:

$$
G D P_{t}=A K_{t}^{\alpha} L_{t}^{\beta}
$$

For purposes of estimates, we have conducted a linearization of this function by applying the logarithm operator. Thus, we have:

$$
\begin{aligned}
\log \left(G D P_{t}\right)= & \log (A)+\alpha * \log \left(K_{t}\right)+\beta \\
& * \log \left(L_{t}\right)
\end{aligned}
$$

The estimation results give us a value of capital elasticity of 0.7 and 0.3 for work one, favoring thus the hypothesis of constant returns to scale. Hence the series of total factor productivity is achieved with the following entry:

$$
T P F_{t}=\frac{G D P_{t}}{K_{t}^{0,7} L_{t}^{0,3}}
$$

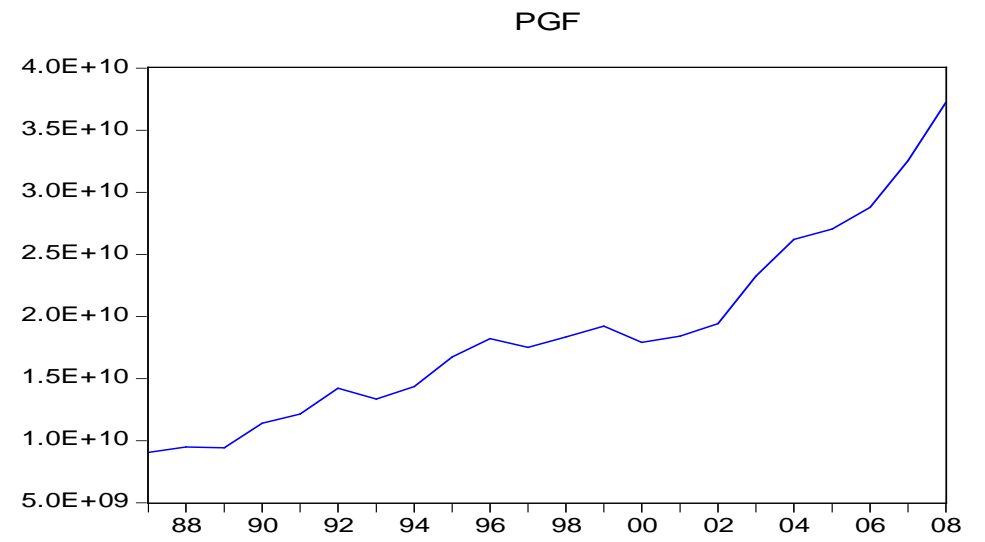

Fig 4: TFP 
We note that the TFP for the entire productive sector described, except a few drops, rather an upward trend which reached its peak in 2008. This reflects a greater efficiency in the use of the production factors. In addition, there was a substantial and regular improvement of the labor quality consequent to the efforts provided in education. Indeed, for a given task, a skilled worker is more effective than an unskilled one, insofar as it can deal more easily with the new technologies. We are also witnessing an improvement in the capital input quality with the import of technology- incorporating capital goods. In an economy like the Tunisian one, where the production of such goods is not yet sufficiently developed, strengthening the quality of equipment is largely dependent on foreign technological progress, technology transfer taking place to a large extent by importing capital goods.

\section{III-2 Definition of the Estimation Model and Empirical Analysis}

In accordance with theoretical expectations, the technology transfer is driven by a process of changing structures and institutions that make up any economic system of an emerging country (Levin 1997). It is, therefore, important to know how and under what conditions such a transfer process takes shape and what its implications in terms of integration are. It should be noted that the acquisition of a new technology is subject to the appropriateness of the transfer. This requires the control and adaptation of these technologies to the local endowments and the efficiency of research and development strategies.

The combination of these factors ensures the smooth conditions of learning, the assimilation and the exploitation of knowledge and the know-how to promote the restructuring of the productive system following the productivity improvement. This leads to the consolidation of the exports competitiveness, the improvement of the export performance and consequently the success of the integration.

Our model is to determine, first, how the diffusion of imported technology supports to improve the productive combination of the economy through its impact on the total factor productivity (Equation 1). If this relationship holds, we move to the empirical investigation of the impact of this transfer on the degree of integration of Tunisia in the EU market (Equation 2). The estimate, first, the first equation is mandatory since it would be absurd to test the effect on the integration of the Tunisian economy if the productivity was not improved after the transfer operation.

Remember, to match, that the choice of studying the integration with the EU market is motivated by the fact that on the one hand, $80 \%$ of our trade is with EU countries and successful integration into the global market inevitably passes through the successful anchor in the European space, on the other. To achieve this we estimate the following two equations:

$$
\left\{\begin{array}{l}
\log \left(T P F_{t}\right)=\alpha_{0}+\alpha_{1} \log \left(\frac{M_{t}}{G D P_{t}}\right)+\alpha_{2} \log \left(\frac{F D I_{t}}{G D P_{t}}\right)+\alpha_{3} \log \left(C A_{t}\right)+\alpha_{4} \log \left(D T M_{t}\right)+\alpha_{5} \log \left(C A_{t} * D T M_{t}\right) \\
\log \left(T_{-} O\right)=\beta_{0}+\beta_{1} \log \left(\frac{M_{t}}{G D P_{t}}\right)+\beta_{2} \log \left(\frac{F D I_{t}}{G D P_{t}}\right)+\beta_{3} \log \left(C A_{t}\right)+\beta_{4} \log \left(D T M_{t}\right)+\beta_{5} \log \left(C A_{t} * D T M_{t}\right)
\end{array}\right.
$$

$\mathrm{TO}=\frac{M_{t}}{G D P_{t}}$ the opening rate which expresses the degree of integration of the Tunisian economy in the European market

$\frac{M_{t}}{G D P_{t}}:$ The share of foreign direct investment from the EU in the Tunisian GDP
$C A_{t} * D T M_{t}$ indicates the indispensability of absorptive capacity for the successful technology transfer process.

$\alpha_{0}$ is the initial level of productivity in the absence of technology transfer 
$\alpha \mathrm{i} i=1 \ldots .5$ represent the elasticities to TFP

$\beta_{0}$ represents the degree of the integration in the absence of initial technology transfer $\beta \mathrm{i}, \mathrm{i}=1 \ldots .5$ represent the elasticities relative to the rate of opening

\section{Estimating Equation}

Table $n^{\circ}$ 3: Impact of the Technology Diffusion on Productivity

Dependent Variable: LOG(TPF)

Method: Least Squares

Date: 11/25/10 Time: 13:20

Sample (adjusted): 19872008

Included observations: 20 after adjustments

\begin{tabular}{lrlrr}
\hline \hline & Coefficient & Std. Error & t-Statistic & Prob. \\
\hline \hline LOG(FDI) & -0.203104 & 0.087648 & -2.317256 & 0.0361 \\
LOG(CA) & 2.536390 & 0.405435 & 6.255971 & 0.0000 \\
LOG(DTM) & -0.710204 & 0.215787 & -3.291229 & 0.0054 \\
LOG(CA_DTM) & 1.394663 & 0.464818 & 3.000449 & 0.0095 \\
LOG(M_GDP) & -0.030989 & 0.281285 & -0.110170 & 0.9138 \\
\multicolumn{1}{c}{ C } & 8.781262 & 2.381373 & 3.687479 & 0.0024 \\
\hline \hline & & & & \\
R-squared & 0.953536 & Mean dependent var & 23.51420 \\
Adjusted R-squared & 0.936942 & S.D. dependent var & 0.345926 \\
S.E. of regression & 0.086867 & Akaike info criterion & -1.805559 \\
Sum squared resid & 0.105641 & Schwarz criterion & -1.506840 \\
Log likelihood & 24.05559 & Hannan-Quinn criter. & -1.747246 \\
F-statistic & 57.46203 & Durbin-Watson stat & 1.538042 \\
Prob(F-statistic) & 0.000000 & & \\
\hline \hline
\end{tabular}

In this table we have attempted to determine the effect of technological diffusion on the level of the total factor productivity. The results clearly show the positive effect of technology diffusion on productivity. In fact, this regression shows that the coefficients CA * DTM, CA and X / Y are significant and positive.

Furthermore, the effect of absorptive capacity on TFP is very remarkable. Indeed, an improvement in the absorption of foreign technology of $1 \%$ generates a $2.5 \%$ increase in Tunisian productivity.
TFP is well explained by the absorptive capacity that facilitates easy absorption of foreign technology. While the persistence of negative effect $(-0.030989)$ of the importation, although not significant (0.9138>0.05), implies that the effective use of foreign technologies is a necessary condition to take advantage of the opening, but it is not sufficient. Thus, we conclude that the process of knowledge accumulation in Tunisia is quite slow and therefore it should be required to get beyond the idea of the absorption for the spirit of creation. 
Table $n^{\circ} 4$ : Impact of the Technological Diffusion on the Degree of Integration

Dependent Variable: LOG(T_0)

Method: Least Squares

Date: 04/24/11 Time: 19:58

Sample (adjusted): 19872008

Included observations: 20 after adjustments

\begin{tabular}{lrlrr}
\hline \hline & Coefficient & Std. Error & t-Statistic & Prob. \\
\hline \hline LOG(FDI) & -0.040754 & 0.018707 & -2.178603 & 0.0469 \\
LOG(CA) & 0.409620 & 0.086531 & 4.733802 & 0.0003 \\
LOG(DTM) & -0.123154 & 0.046055 & -2.674083 & 0.0182 \\
LOG(CA_DTM) & 0.167755 & 0.099205 & 1.690993 & 0.1130 \\
LOG(M_GDP) & 0.818997 & 0.060034 & 13.64228 & 0.0000 \\
\multicolumn{1}{c}{ C } & -1.696562 & 0.508250 & -3.338049 & 0.0049 \\
\hline \hline & & & & \\
R-squared & 0.985687 & Mean dependent var & -0.627119 \\
Adjusted R-squared & 0.980575 & S.D. dependent var & 0.133023 \\
S.E. of regression & 0.018540 & Akaike info criterion & -4.894479 \\
Sum squared resid & 0.004812 & Schwarz criterion & -4.595760 \\
Log likelihood & 54.94479 & Hannan-Quinn criter. & -4.836166 \\
F-statistic & 192.8291 & Durbin-Watson stat & 1.522459 \\
Prob(F-statistic) & 0.000000 & & \\
\hline \hline
\end{tabular}

In this table we have tried to determine the effect of the technological diffusion on the degree of integration of Tunisia in the European market. The results compiled in the table above clearly show the positive effect of technological diffusion on exports. In fact, this regression shows that the coefficients CA, CA * DTM M_GDP are significant and positive.

Furthermore, the effect of absorption on the rate of opening is very remarkable. Indeed, an improvement of the absorption of foreign technology of $1 \%$ leads to a consolidation of the opening ratio of $0.96 \%$. Such results reflect that the efficient exploitation of imported technology affects significantly the penetration degree of Tunisia into the European market. This efficiency in the use of foreign technologies is conditioned, all things being equal, by the absorptive capacity.

The degree of integration is well explained by the absorptive capacity that promotes easy absorption of foreign technology. Thus, we can deduce a priori that a good absorption of imported technology is likely to promote the integration of Tunisia insofar as the Tunisian economy will have the opportunity to exploit these technologies less expensively than the innovative country, use them for the development of new products with high technological content whose global demand is continuously growing. Moreover, in a more optimistic scenario, this transaction represents for Tunisia, an occurrence for the creation of its own technology that it would be irrational to miss. However, the of accumulation knowledge process in Tunisia is quite slow. It is strongly recommended to overcome as quickly as possible this optic of absorption to the spirit of creation. It is at this point that we can actually consider the integration of Tunisia as crown of success.

Two main conclusions can be made:

- The trade between a developing country and a developed country like the case of Tunisia and the EU, with the lack of 
technological expertise, may slow down the integration process.

- The technology transfer process cannot be beneficial unless the country possesses human capital able to absorb and create new technologies.

The results reveal that a positive relationship between technology transfer and integration is not automatic, so far. Indeed, it would be wiser to consider the transfer of technology as an enabler and not as an engine of integration. This observation will be further highlighted through the estimation of the interaction between the technology diffusion and the absorptive capacity in the next two paragraphs.

\section{- Interaction between the Technology Diffusion and the Absorptive Capacity}

To demonstrate the indispensability of absorptive capacity in the success of the technology diffusion we move to the following estimates:

$$
\log \left(T P F_{t}\right)=\alpha_{0}+\alpha_{1} \log \left(C A_{t} * D T M_{t}\right) * d u m m y_{t}
$$

Dummy $_{t}$ : Dummy variable introduced to capture structural changes that have occurred in Tunisia after 1996 (entry into force of the free trade agreement with the
European Union). It takes the value zero before 1996 and the value one later.

And

$$
\log \left(\frac{X_{t}}{G D P_{t}}\right)=\beta_{0}+\beta_{1} \log \left(C A_{t} * D T M_{t}\right) * d u m m y_{t}
$$

Dummy : Dummy variable introduced to capture structural changes that have occurred in Tunisia after 1996 (entry into force of the free trade agreement with the European Union). It takes the value zero before 1996 and the value one later.
We obtain the results summarized in the two tables in which the endogenous variable is either productivity or the degree of integration:

\section{Tableau ${ }^{\circ}$ 5: The Endogenous Variable is the Productivity}

Dependent Variable: LOG(TPF)

Method: Least Squares

Date: $11 / 25 / 10$ Time: 13:29

Sample: 19872008

\begin{tabular}{|c|c|c|c|c|}
\hline & Coefficient & Std. Error & t-Statistic & Prob. \\
\hline LOG(CA_DTM)*DUMMY & 0.104277 & 0.018290 & 5.701161 & 0.0000 \\
\hline $\mathrm{C}$ & 23.24794 & 0.079632 & 291.9436 & 0.0000 \\
\hline R-squared & 0.619071 & \multicolumn{2}{|c|}{ Mean dependent var } & 23.58320 \\
\hline Adjusted R-squared & 0.600025 & \multicolumn{2}{|c|}{ S.D. dependent var } & 0.398226 \\
\hline S.E. of regression & 0.251853 & \multicolumn{2}{|c|}{ Akaike info criterion } & 0.166562 \\
\hline Sum squared resid & 1.268594 & \multicolumn{2}{|c|}{ Schwarz criterion } & 0.265747 \\
\hline Log likelihood & 0.167821 & \multicolumn{2}{|c|}{ Hannan-Quinn criter. } & 0.189927 \\
\hline F-statistic & 32.50323 & \multicolumn{2}{|c|}{ Durbin-Watson stat } & 0.490627 \\
\hline Prob(F-statistic) & 0.000014 & & & \\
\hline
\end{tabular}

Included observations: 22 
The estimation of equation (3) with the results shown in the table, confirm the conclusion that foreign technology isn't able to boost the productivity of Tunisia, unless the host country has the absorptive capacity for the reabsorb.

Indeed, a $1 \%$ increase in the absorption of foreign technology increases productivity by $0.1 \%$. These coefficients show that the correlation-although weak- is positive between the two variables. The existence of this capacity is the result of the Government policy which has granted substantial importance to education, the coaching and the training as well as the research and development, which are the pillars of the construction and the consolidation of the absorptive capacity. In fact, this ability, allowing a good understanding and control of imported technologies, is likely to promote the modernization and the upgrades of the production process. Human capital affects indeed, the TFP in determining the country's ability to innovate on the one hand, and absorb, facilitate the dissemination and take advantage of new technologies, on the other hand. In addition, improving the capacity of some subgroups of the workforce has been spillover effects on the rest of the workforce in increasing the efficiency of employees having a lower qualification level.

In contrast, the low correlation coefficient reflects the inadequacy of the ability to absorb the technology available to Tunisia. It must be admitted that despite the progress made in the field of the education, there are still distortions both quantitative and qualitative in this area, especially at higher levels. These differences are extreme technical matters insofar as the country shows a mismatch between the skills imparted in schools and training institutions and those required by the industry. Unfortunately, Tunisia still suffers from imbalances in terms of the adequacy of the training of graduates and business needs. In addition, many skills at modern information technologies are not insured by the training systems. The availability of an educated workforce and suitable training is insufficient to meet the needs of sectors of goods and services which need to be competitive and technologically sophisticated. Finally, the international demand, which is increasingly oriented to products based on knowledge and high skills, requires a workforce gifted to adapt quickly, with the necessary retraining, to grasp the opportunities that arise.

\section{Tableau $n{ }^{\circ}$ 6: The Endogenous Variable is the Integration Degree}

Dependent Variable: LOG(X_GDP)

Method: Least Squares

Date: 11/25/10 Time: 13:29

Sample: 19872008

Included observations: 22

\begin{tabular}{lrlrr}
\hline \hline & Coefficient & Std. Error & t-Statistic & Prob. \\
\hline \hline \multicolumn{1}{c}{ LOG(CA_DTM)*DUMMY } & 0.048337 & 0.007658 & 6.311668 & 0.0000 \\
\multicolumn{1}{c}{ C } & -1.591838 & 0.033342 & -47.74271 & 0.0000 \\
\hline \hline R-squared & 0.665760 & Mean dependent var & -1.436433 \\
Adjusted R-squared & 0.649047 & S.D. dependent var & 0.178003 \\
S.E. of regression & 0.105451 & Akaike info criterion & -1.574624 \\
Sum squared resid & 0.222400 & Schwarz criterion & -1.475439 \\
Log likelihood & 19.32087 & Hannan-Quinn criter. & -1.551259 \\
F-statistic & 39.83715 & Durbin-Watson stat & 0.655150 \\
Prob(F-statistic) & 0.000004 & & \\
\hline \hline
\end{tabular}


The results of the estimation of equation (4), show that foreign technology can't corroborate to stimulate the integration of Tunisia unless it disposes of an absorptive capacity. We note again that the correlation coefficient between the two variables is not interesting. Indeed, a 1\% increase in the absorption of foreign technology increases the opening rate of $0.04 \%$. It is thus evident that the acquisition, adaptation and dissemination of technology strengthen the competitiveness in traditional manufacturing sectors, which are the backbone of the Tunisian industry. Technology, absorbed and assimilated properly, contributes deeply to higher the value added in manufacturing. It is increasingly recognized that in this new context, technology is perhaps the only way for developing countries to improve the terms of trade for traditional exports of manufactured goods. Otherwise, they remain locked in production and exports of a low value-added in discrepancy with the evolution of the global demand, obstructing then, the integration process of Tunisia.

However, this absorption should not remain in a static framework which reduces it to the simple adaptation and control of the technologies received. We claim rather a more dynamic conception which should be adopted by the Govenment and seeking to develop proactive aspects such as the ability to integrate, build and reconfigure internal and external competences of Tunisia to cope with environmental changes. We reach here the findings of Teece et al. (1997), according to which dynamic capabilities are skills closely intertwined in organizational processes and business assets.

In a deeper perspective, the Government will have to implement for the establishment of organizational and strategic processes and routines which would be able to allow the reconfiguration of the company's resources so that it can adapt to new market realities. We emphasize, in addition, the specific processes underlying dynamic capabilities, whether such processes may concern the creation or the access to new knowledge, or the development process of a new product. This is especially in question to develop routines specific to certain essential functions such as the creation and the acquisition of knowledge, or the ability to establish alliances or partnerships.

\section{III-Summary of Results}

The empirical verification of the potential relationship between technological diffusion and integration in the case of Tunisia has confirmed the theoretical findings developed. We found that technology transfer occurs, a priori, as a catalyst for the integration of Tunisia in the EU area. This transfer occurs by technological externalities transmitted through international trade over the import of capital goods and the flow of foreign direct investment.

Our estimates have indeed identified a significant causal relationship between the technology acquired and the increasing of the productivity level on the one hand and the degree of integration of Tunisia expressed by its rate of opening to the EU market on the other. We have established that international trade, more specifically via the importation of goods, is a vector of dissemination of knowledge. These are enclosed in the heart of the imported product that incorporates information technology. Tunisia, at this stage of development, is not able to produce knowledge and has so to resort to foreign countries, especially the EU ones, to make use of imports as a source of technology accumulation. As well as imports of capital goods, FDI represent to Tunisia-not mastering a technological advantage- a substitute or a complement to the development of national research activities.

However, our investigations have shown that the relationship between the transferred technology and the integration cannot be direct and systematic. It is conditioned by the existence of an absorptive capacity of the technology that determines the success of the transfer process. The effect of the acquired technology depends on the ability of Tunisia to assimilate and disseminate these 
technologies developed. That is to say, a developed level of human capital and an effective education and research \& development policy. We reach here the role of institutional factors in the success of the technology transfer process. We wish, moreover, to mark that such capacity must be, however, better scrutinized through the development by the State of more dynamic aspects including the ability to integrate, construct and reconfigure internal and external competences of Tunisia in order to deal with environmental changes. Tunisia is advised to further expand this capacity to absorb foreign technology by implementing organizational or strategic processes and routines for the restructuring of the company's resources so that it can accommodate the new realities of the market.

Needless to mention that the governmental intervention should be directed towards the stimulation of the innovation activity of Tunisian companies. Thus, the commitment to the upgrade program is an effective factor of technological development, particularly, for exporting firms. In fact, Tunisia at this sensitive stage, where it must confront the challenges of the current context marked by the accession to the WTO in 1995, on the one hand, and with the signing in 1996 of the Association Agreement with the EU on the creation of a free trade zone on the other hand seems not to have much choice. These economic factors have forced the Tunisian government's adoption of a new industrial policy whose main objective is to improve the competitiveness of Tunisian industry for successful integration. This competitiveness which, remember, is now dependent on the ability of countries to innovate, relies more than ever on the advantages of new technologies rather than on low-cost production or endowments.

Therefore, improving the competitiveness assumes influencing factors allowing sustained growth in productivity: stable macroeconomic conditions, a competitive market, dissemination of knowledge and a favorable business environment.The Industrial policy of Tunisia is based on a series of instruments to carry out its ultimate objective of integration: more spending on research and development, and a policy of encouraging the creation of innovative companies.

The results that we have come up to, highlight the opportunity offered to Tunisia to achieve its integration objectives in the European market as a first step, and in the global market as a second stage. That said, we note that Tunisia does not benefit adequately from its proximity to Europe to increase exports and attract FDI which remain unattractive up to now.

\section{References}

Adda Jacques (2004). 'La Mondialisation de l'Economie: l. Genèse,' Editions la Découverte, Paris.

Adda Jacques (2004). "La Mondialisation de l'Economie: 2. Problèmes," la Découverte, Paris.

Altinok, N. (2006). Données internationales sur l'éducation (1960-2005), Centre d'Etudes et de Recherches sur les Qualifications.

Amesse, F. \& Cohendet, P. (2001). "Technology Transfer from the Perspective of the Knowledge-Based Economy," Research Policy, 30:1459- 1478.

Arcangelo, F. (2006). Economie Internationale: Faits, Théories et Débats Contemporains, Editions Ellipses, Paris.

Argote, L., Ingram, P., Levine, J. M. \& Moreland, R. L. (2000). "Knowledge Transfer: A Basis for Competitive Advantage in Firms," Organizational Behaviour and Human Decision Process, 82 (1): 150-169.

Ayerbe-Machat, C. (2003). "Innovations Technologique et Organisationnelle au Sein des PME Innovantes: Complémentarité des Processus, Analyse Comparative des Mécanismes de Diffusion," XIIè Conférence de L'Association Internationale de Management Stratégique, Les côtes de Carthage, Tunisie 3-6 Juin. 
Banque Centrale (2010). "Périodique de Conjoncture," Edition n0.

Banque Centrale (2010). "Rapport Annuel 2009,"

Bellon, B. \& Youssef, A. (2003). "Intégration Euro-Méditerranéenne: Vers un Partenariat Technologique," Séminaire EMMA-RINOS, 26-27 Mai Paris.

Boulaouadnine, L. (2004). "Processus D'acquisition de la Technologie et Apprentissage Technologique Dans le Secteur Automobile au Maroc," Séminaire Doctoral Du GDRI EMMA, Université de Nice Sophia Antipolis.

Cohen, W. M. \& Levinthal, D. A. (1990). "Absorptive Capacity: a New Perspective on Learning and Innovation," Administrative Science Quaterly, 35(1), pp. 128-152.

CNUCED (2002). 'Liens Entre la Concurrence, la Compétitivité et le Développement,' Note Thématique $d u$ Secrétariat de la CNUCED.

CNUCED (2002). "L'intégration de la Tunisie dans L'économie Mondiale: Opportunités et Défis," par Francesco Abbate.

CNUCED (2003). "Investment and Technology Policies for Competitiveness Review of Successful Country Experiences," Note du secretariat de la CNUCED.

CNUCED (2006). "Promotion de Liens Entre STN et PME en vue de Renforcer la Capacité Productive des Entreprises des Pays en Développement: une Perspective Stratégique," Note Thématique du Secrétariat de la CNUCED.

CNUCED (2007). 'Savoir, Apprentissage Technologique et Innovation Pour le Développement,' Rapport 2007 sur les pays les Moins Avancés, Note du secrétariat de la CNUCED.

CNUCED (2008). 'Mettre à Profit les Connaissance et la Technologie pour le Développement,' Note du secrétariat de la CNUCED.
CNUCED (2010). 'Investissement Etranger Direct, Transfert et Diffusion de la Technologie, et Développement Durable,' Note du secrétariat de la CNUCED.

Fabrizio, K. R. (2009). "Absorptive Capacity and the Search for Innovation," Research Policy, n³8(2), p. 255-267.

Guelloz, S. (2008). 'Concordance des Objectifs Stratégiques: Développement de Long Terme et Localisation des Entreprises Etrangère en Tunisie,' Colloque International de Tunis le 8 et 9 Février 2008: «la Mondialisation: Intégration Economique et Croissance en Méditerranée occidentale».

Guilhon, B. (2001). 'Les Indicateurs Technologiques,' Document de Travail, CEFI, UMR-CNRS.

Hendrickx, C. (1996). "Problématique du Transfert de Technologie et Nouvelles Théories de L'innovation et de la Firme," Revue Région et Développement, $n^{\circ} 3$.

Kumar, M. V. (2009). "The Relationship between Product and International Diversification: the Effects of Short-run Constraints and Endogeneity," Strategic Management Journal, n³0(1), p. 99-116.

Liouane, N. \& Teffahi, B. (2006). La Diffusion Technologique par le Commerce International, le Rôle de la Capacité D'absorption (Etude Empirique Entre les Pays de l'OCDE et les Pays MENA).

Missonier, A. \& Guallino, G. (2005). 'Une Analyse du Processus de Transfert des Compétences Technologiques Dans le Cadre d'une Fusion Dans le Secteur des TIC,' XIVième Conférence Internationale de Management Stratégique, Pays de la Loire.

Postel-Vinay, O., Fourel. J, Belitz et al (2005). 'La Recherche \& Développement à L'épreuve de la Mondialisation,' Problèmes Economiques $\mathrm{n}^{\circ} 2869$, Décembre.

Siroên, J. M. (2000). "La Régionalisation de L'économie Mondiale," Paris, La Découverte, Repères. 